Kong. Res. J. 4(2): 52-56, 2017

ISSN 2349-2694

Kongunadu Arts and Science College, Coimbatore.

\title{
IN VITRO REGENERATION AND MASS PROPAGATION OF AZIMA TETRACANTHA [LAM.] FROM THE LEAF EXPLANTS THROUGH CALLUS CULTURE
}

\author{
Mallika Devi, T. \\ PG and Research Department of Botany, Kandaswamy Kandar's College, P. Velur, Namakkal - 638182. \\ E.mail: tmallikadevi@yahoo.com
}

\begin{abstract}
In the present study the protocol for callus induction and regeneration in Azima tetracantha has been developed in culture medium. The young apical leaf explants were used for callus induction on MS medium containing BAP and NAA at 1.0 and $0.4 \mathrm{mgl}^{-1}$ respectively showed maximum callus induction (73\%). The amount of callus responded for shoot formation (74\%) was obtained in the MS medium containing BAP (1.5 $\left.\mathrm{mgl}^{-1}\right)$ and NAA $\left(0.3 \mathrm{mgl}^{-1}\right)$.The elongated shoots were rooted on half strength medium supplemented with IBA $\left(1.5 \mathrm{mgl}^{-1}\right)$ and $\mathrm{Kn}\left(0.4 \mathrm{mgl}^{-1}\right)$ for shoots rooted. Regenerated plantlets were successfully acclimatized and hardened off inside the culture and then transferred to green house with better survival rate.
\end{abstract}

Keywords: Azima tetracantha, MS medium, Growth hormones, Acclimatization.

\section{INTRODUCTION}

India is richly endowed with a wide variety of plants having medicinal value. These plants are widely used by all sections of the society whether directly as folk medicines or indirectly as pharmaceutical preparation of modern medicine (Uniyal, 2003). In India, thousands of medicinal plant species are known to have medicinal value to cure specific ailments. However, it is estimated that about 15,000 species of medicinal plants are globally threatened; the causes include loss of habitat, over harvesting and pollution. Biotechnological tools are important for the multiplication and the genetic enhancement of the medicinal plants by adopting techniques such as in vitro regeneration and genetic transformation. Microprobagation method is specifically applicable to species in which clonal propagation is needed (Gamborg and Phillips, 1995). Among the important medicinal plant species, one of the species Azima tetracantha belongs to the family Salvadoraceae. It is a potent diuretic to treat rheumatism, dropsy, dyspepsia, chronic diarrhorea; it is used as stimulant tonic after child birth. $A$. tetracantha is used to treat cough, phthisis, asthma, small pox and diarrhorea. Rheumatism has been cured by its leaves, root and root bark. Leaves are used as stimulant, expectorant and antispasmodic. It is also used in cough and asthma. Bark is used as antiperiodic, astringent and expectorant. In western India, juice of the leaves is applied as ear drops against earache and crushed leaves are placed on painful teeth. In India and Sri Lanka the root, root bark and leaves were administered with food as a remedy for rheumatism, dropsy, dyspepsia, chronic diarrhea and is considered as stimulant tonic and given to pubertal women immediately after confinement. Locally, the traditional healers from Tirunelveli district of Tamilnadu use the root bark (paste with buttermilk) as potent remedy for jaundice. This paper describes the first results of experiments carried out to induce organogenesis in tissue culture of Azima tetracantha under influence of different combinations of growth regulators.

\section{MATERIALS AND METHODS}

Leaf segments from young and healthy branches of $A$. tetracantha were used as explants. They were collected from pot cultured individuals maintained in a mist chamber. For surface sterilization, the collected immature leaves were washed with tap water twice and then treated with 5 $\%$ tween-20 solutions for 5 min followed by rinsing in tap water. To eliminate fungal contamination, explants were further treated with $5 \%$ antibiotics (Amphicillin and Rifampicin) for $30 \mathrm{~min}$ followed by 3 rinses in sterile double distilled water. Further, surface sterilization was carried out by dipping the explants in $0.1 \% \mathrm{HgCl}_{2}$ for $3 \mathrm{~min}$ followed by 3-4 rinses in sterile double distilled water.

\subsection{Media and culture condition}

Murashige and Skoog (MS) (1962), medium containing $3 \%$ sucrose solidified with $1 \%$ agar (tissue culture grade, Himedia, India) was used. The $\mathrm{pH}$ of the medium was adjusted to 5.6-5.8 prior to the addition of agar before autoclaving at $121^{\circ} \mathrm{C}$ for $15 \mathrm{~min}$. All the culture bottles were kept in culture chamber at $25 \pm 2^{\circ} \mathrm{C}$ under $16 / 8 \mathrm{hr}$ (light/dark) photoperiod with a light intensity of 2000 lux supplied by cool white fluorescent tubes and with $60-65 \%$ relative humidity. 


\subsection{Callus induction medium}

The explants were transferred to culture bottles containing $25 \mathrm{ml}$ MS medium supplemented with different concentrations and combinations of BAP and NAA for callus induction.

\subsection{Shoot induction medium}

MS medium containing different concentrations and combinations of BAP $(0.3,0.6$, $0.9,1.2,1.5$ and $1.8 \mathrm{mg} / \mathrm{l}$ ) and NAA at $0.3 \mathrm{mg} / \mathrm{l}$ was used for shooting attributes.

\subsection{Rooting of elongated shoots and acclimatization}

After proper shoot induction, the plantlets were carefully removed from the medium and washed with sterilize double distilled water properly, so as to avoid any trace of medium on roots. In vitro regenerated shoots (5-6 cm long) were excised and transferred onto the rooting media containing half strength MS medium supplemented with IBA and $\mathrm{Kn}$ for rooting. After proper root formation, these rooted plantlets were transferred to hardening medium composed by garden soil, sand and vermicompost in different proportion and maintained in greenhouse condition to know the survivability rate.

\subsection{Statistical Analysis}

All the experiment was done atleast twice using triplicate. The data was statistically processed and means were compared using Duncan's Multiple Range Test $(P<0.05)$.

\section{RESULTS AND DISCUSSION}

The Calli formation was observed in leaf explants after 26 days. The best response of callus (73\%) was observed in the MS medium supplemented with cytokinin BAP $\left(1.0 \mathrm{mgl}^{-1}\right)$ and auxin, NAA (0.4 $\mathrm{mgl}^{-1}$ ) (Table 1). A similar result was shown by Thambiraj and Paulsamy (2012). Further studies were carried out for shoot regeneration capacity of the callus. Shoots were initiated from the callus obtained leaf explants. The best result of shooting $(74 \%)$ was observed on the MS medium fortified with BAP (1.5 mgl-1) and NAA $\left(0.3 \mathrm{mgl}^{-1}\right)$. The maximum number of multiple shoots 9.06 shoots/callus and shoot length $(6.8 \mathrm{~cm})$ were produced in the same concentrations and combinations of growth regulators (Table 2). The superiority of BAP over the other cytokinins on shoot bud production and prolifehration of shoots has been reported for several medicinal and aromatic plant species by Jebakumar and Jayabalan, 2000; Hussain and Anis, 2006; Raja et al., 2008; Faisal and Anis, 2003 and Chakradhar and Pullaih, 2014.

Table 1. Effect of growth regulators on callus induction from leaf explants of the species, Azima tetracantha.

\begin{tabular}{|c|c|c|c|c|c|}
\hline \multicolumn{4}{|c|}{ Growth regulators (mg/l) } & \multirow{2}{*}{$\begin{array}{c}\text { Days required for callus } \\
\text { formation after inoculation } \\
\text { Leaf Explant }\end{array}$} & \multirow{2}{*}{$\begin{array}{c}\text { Callus formation (\%) } \\
\text { Leaf Explant }\end{array}$} \\
\hline BAP & 2, 4-D & NAA & IAA & & \\
\hline 0.2 & 0.0 & 0.4 & 0.0 & 16 & $39.21^{\mathrm{g}} \pm 0.82$ \\
\hline 0.4 & 0.0 & 0.4 & 0.0 & 19 & $48.02^{\mathrm{h}} \pm 1.63$ \\
\hline 0.6 & 0.0 & 0.4 & 0.0 & 24 & $60.34^{j} \pm 0.82$ \\
\hline 0.8 & 0.0 & 0.4 & 0.0 & 25 & $67.14^{1} \pm 1.63$ \\
\hline 1.0 & 0.0 & 0.4 & 0.0 & 26 & $73.23^{\mathrm{i}} \pm 1.63$ \\
\hline 1.2 & 0.0 & 0.4 & 0.0 & 25 & $65.18^{i} \pm 0.82$ \\
\hline 0.0 & 0.3 & 0.3 & 0.0 & 18 & $25.56^{\mathrm{a}} \pm 1.63$ \\
\hline 0.0 & 0.6 & 0.3 & 0.0 & 20 & $33.76^{b} \pm 0.82$ \\
\hline 0.0 & 0.9 & 0.3 & 0.0 & 21 & $39.17^{c} \pm 1.63$ \\
\hline 0.0 & 1.2 & 0.3 & 0.0 & 26 & $44.46^{\mathrm{f}} \pm 1.63$ \\
\hline 0.0 & 1.5 & 0.3 & 0.0 & 25 & $55.00^{\mathrm{h}} \pm 0.82$ \\
\hline 0.5 & 0.0 & 0.0 & 0.2 & 18 & $25.21^{b} \pm 1.63$ \\
\hline 1.0 & 0.0 & 0.0 & 0.4 & 20 & $31.38^{d} \pm 1.63$ \\
\hline 1.5 & 0.0 & 0.0 & 0.6 & 23 & $58.45^{g} \pm 1.63$ \\
\hline 2.0 & 0.0 & 0.0 & 0.8 & 24 & $69.64^{\mathrm{h}} \pm 0.82$ \\
\hline 2.5 & 0.0 & 0.0 & 1.0 & 26 & $70.32^{\mathrm{i}} \pm 1.63$ \\
\hline 3.0 & 0.0 & 0.0 & 1.2 & 26 & $54.17^{i} \pm 1.63$ \\
\hline 0.0 & 0.3 & 0.0 & 0.3 & 15 & $15.89^{a} \pm 0.82$ \\
\hline 0.0 & 0.6 & 0.0 & 0.3 & 17 & $23.43^{\mathrm{b}} \pm 0.82$ \\
\hline
\end{tabular}




\begin{tabular}{cccccc}
0.0 & 0.9 & 0.0 & 0.3 & 18 & $41.00^{\mathrm{d}} \pm 0.82$ \\
0.0 & 1.2 & 0.0 & 0.3 & 20 & $46.00^{\mathrm{e}} \pm 1.63$ \\
0.0 & 1.5 & 0.0 & 0.3 & 19 & $47.00^{\mathrm{e}} \pm 1.63$ \\
\hline \multicolumn{5}{c}{ Means in columns followed by different letter (s) are significant to each other at $5 \%$ level according to } \\
DMRT.
\end{tabular}

Table 2. Effect of different concentrations of growth regulators on shoot initiation, shoot number and shoot length after the subculturing of leaf derived callus of the species, Azima tetracantha.

\begin{tabular}{|c|c|c|c|c|c|c|c|}
\hline \multicolumn{5}{|c|}{ Growth regulators (mg/l) } & \multirow{2}{*}{-Culture response $(\%)$} & \multirow{2}{*}{ No. of shoots/callus } & \multirow{2}{*}{ Shoot length $(\mathrm{cm})$} \\
\hline BAP & NAA & Kn & IBA & $\mathbf{G A}_{3}$ & & & \\
\hline 0.5 & 0.0 & 0.0 & 0.3 & 0.0 & $24.02^{\mathrm{a}} \pm 0.82$ & $2.47 \mathrm{abc} \pm 0.82$ & $1.4^{\mathrm{a}} \pm 0.82$ \\
\hline 1.0 & 0.0 & 0.0 & 0.3 & 0.0 & $32.17^{\mathrm{fg}} \pm 1.63$ & $3.12^{\mathrm{ab}} \pm 1.63$ & $2.6^{\mathrm{abc}} \pm 0.82$ \\
\hline 1.5 & 0.0 & 0.0 & 0.3 & 0.0 & $49.10^{\mathrm{h}} \pm 0.82$ & $4.23^{\mathrm{bcd}} \pm 0.82$ & $3.0^{\mathrm{abc}} \pm 1.63$ \\
\hline 2.0 & 0.0 & 0.0 & 0.3 & 0.0 & $45.78^{c} \pm 1.63$ & $6.42^{\mathrm{def}} \pm 1.63$ & $3.5^{\mathrm{abc}} \pm 0.82$ \\
\hline 2.5 & 0.0 & 0.0 & 0.3 & 0.0 & $43.24^{\mathrm{de}} \pm 0.82$ & $5.18^{\text {cde }} \pm 1.61$ & $4.6^{\mathrm{abc}} \pm 0.82$ \\
\hline 3.0 & 0.0 & 0.0 & 0.3 & 0.0 & $42.27^{\mathrm{cd}} \pm 1.63$ & $4.00^{\mathrm{bcd}} \pm 0.82$ & $3.2^{\mathrm{abc}} \pm 1.63$ \\
\hline 0.3 & 0.3 & 0.0 & 0.0 & 0.0 & $38.48^{\mathrm{h}} \pm 1.63$ & $3.65^{\text {cde }} \pm 0.82$ & $3.8^{\mathrm{abc}} \pm 1.63$ \\
\hline 0.6 & 0.3 & 0.0 & 0.0 & 0.0 & $47.00^{i} \pm 0.82$ & $4.49^{\mathrm{efg}} \pm 1.63$ & $4.4^{\mathrm{abc}} \pm 0.82$ \\
\hline 0.9 & 0.3 & 0.0 & 0.0 & 0.0 & $60.43^{j} \pm 1.63$ & $5.38^{\mathrm{def}} \pm 2.45$ & $5.6^{\mathrm{bc}} \pm 1.63$ \\
\hline 1.2 & 0.3 & 0.0 & 0.0 & 0.0 & $65.67^{i} \pm 1.63$ & $7.47^{\mathrm{hi}} \pm 1.63$ & $5.8^{b c} \pm 1.63$ \\
\hline 1.5 & 0.3 & 0.0 & 0.0 & 0.0 & $74.42^{\mathrm{k}} \pm 0.82$ & $9.06^{\mathrm{i}} \pm 1.21$ & $6.8^{c} \pm 0.82$ \\
\hline 1.8 & 0.3 & 0.0 & 0.0 & 0.0 & $58.46^{\mathrm{h}} \pm 1.63$ & $7.98^{\mathrm{ghi}} \pm 0.82$ & $4.7^{\mathrm{abc}} \pm 0.82$ \\
\hline 0.5 & 0.0 & 0.2 & 0.0 & 0.0 & $32.38^{\mathrm{g}} \pm 0.82$ & $4.66^{\mathrm{fgh}} \pm 0.82$ & $3.4^{\mathrm{abc}} \pm 1.63$ \\
\hline 1.0 & 0.0 & 0.2 & 0.0 & 0.0 & $39.00^{\mathrm{de}} \pm 0.82$ & $4.22^{\mathrm{def}} \pm 1.63$ & $3.9^{\mathrm{abc}} \pm 0.82$ \\
\hline 1.5 & 0.0 & 0.2 & 0.0 & 0.0 & $48.67^{h} \pm 1.63$ & $5.16^{\mathrm{abc}} \pm 1.63$ & $4.7^{\mathrm{abc}} \pm 0.82$ \\
\hline 2.0 & 0.0 & 0.2 & 0.0 & 0.0 & $52.89^{i} \pm 0.82$ & $3.08^{\mathrm{ab}} \pm 0.12$ & $4.8^{\mathrm{a}} \pm 0.82$ \\
\hline 2.5 & 0.0 & 0.2 & 0.0 & 0.0 & $55.55^{j} \pm 0.82$ & $2.67^{a} \pm 0.62$ & $5.0^{\mathrm{abc}} \pm 1.63$ \\
\hline 3.0 & 0.0 & 0.2 & 0.0 & 0.0 & $59.26^{\mathrm{h}} \pm 1.63$ & $3.47^{b c d} \pm 0.31$ & $3.4^{\mathrm{abc}} \pm 0.82$ \\
\hline 0.5 & 0.0 & 0.0 & 0.0 & 0.3 & $33.12^{\mathrm{i}} \pm 0.82$ & $4.65^{\text {cde }} \pm 1.63$ & $3.6^{\mathrm{abc}} \pm 1.63$ \\
\hline 1.0 & 0.0 & 0.0 & 0.0 & 0.3 & $39.66 j \pm 0.82$ & $5.86^{\mathrm{abc}} \pm 1.63$ & $4.2^{\mathrm{abc}} \pm 1.63$ \\
\hline 1.5 & 0.0 & 0.0 & 0.0 & 0.3 & $44.37^{\mathrm{g}} \pm 0.82$ & $6.46^{a} \pm 0.82$ & $4.0^{\mathrm{abc}} \pm 0.82$ \\
\hline 2.0 & 0.0 & 0.0 & 0.0 & 0.3 & $55.47^{\mathrm{ef}} \pm 1.63$ & $5.14^{\mathrm{ab}} \pm 0.82$ & $3.8^{\mathrm{abc}} \pm 0.82$ \\
\hline 2.5 & 0.0 & 0.0 & 0.0 & 0.3 & $67.76^{\mathrm{cd}} \pm 1.63$ & $4.56^{\mathrm{bcd}} \pm 1.63$ & $3.1^{\mathrm{abc}} \pm 1.63$ \\
\hline 3.0 & 0.0 & 0.0 & 0.0 & 0.3 & $42.00^{\mathrm{b}} \pm 0.82$ & $4.98^{\mathrm{def}} \pm 0.82$ & $2.7^{\mathrm{abc}} \pm 0.82$ \\
\hline
\end{tabular}

Table 3. Effect of different concentrations of growth regulators on rooting percentage, root number and root length after subculturing the leaf derived callus of the species, Azima tetracantha.

\begin{tabular}{lcclll}
\hline \multicolumn{2}{l}{ Growth regulators $(\mathbf{m g} / \mathbf{l})$} & \multirow{2}{*}{ Shoots rooted (\%) } & No. of roots/shoot & Root length (cm) \\
\cline { 1 - 3 } IBA & IAA & $\mathbf{K n}$ & & & \\
\hline 0.5 & 0.2 & 0.0 & $36.16^{\mathrm{b}} \pm 0.21$ & $3.75^{\mathrm{abc}} \pm 0.16$ & $2.9^{\mathrm{a}-\mathrm{d} \pm 0.40}$ \\
1.0 & 0.2 & 0.0 & $38.79^{\mathrm{d}} \pm 1.63$ & $3.96^{\mathrm{abc}} \pm 0.41$ & $3.1^{\mathrm{ab}} \pm 0.65$ \\
1.5 & 0.2 & 0.0 & $42.09^{\mathrm{e}} \pm 0.34$ & $4.18^{\mathrm{bcd}} \pm 1.23$ & $3.5^{\mathrm{abc}} \pm 0.81$ \\
2.0 & 0.2 & 0.0 & $46.43^{\mathrm{g}} \pm 0.41$ & $4.25^{\mathrm{abc}} \pm 0.82$ & $4^{\mathrm{c}-\mathrm{f}} \pm 0.21$ \\
2.5 & 0.2 & 0.0 & $50.14^{\mathrm{h}} \pm 1.63$ & $5.26^{\mathrm{cde} \pm 0.12}$ & $4.9^{\mathrm{ef}} \pm 0.33$ \\
3.0 & 0.2 & 0.0 & $44.10^{\mathrm{d}} \pm 0.17$ & $4.56^{\mathrm{bcd}} \pm 1.61$ & $3.8^{\mathrm{b}-\mathrm{e}} \pm 0.42$ \\
0.3 & 0.0 & 0.4 & $42.11^{\mathrm{c}} \pm 0.65$ & $3.76^{\mathrm{abc}} \pm 0.41$ & $3.0^{\mathrm{abc}} \pm 0.12$ \\
0.6 & 0.0 & 0.4 & $52.45^{\mathrm{e}} \pm 1.63$ & $4.38^{\mathrm{bcd}} \pm 0.17$ & $3.8^{\mathrm{abc}} \pm 1.61$ \\
0.9 & 0.0 & 0.4 & $57.07^{\mathrm{fg}} \pm 0.41$ & $5.38^{\mathrm{a}} \pm 0.82$ & $4.2^{\mathrm{b}-\mathrm{e}} \pm 0.19$
\end{tabular}




\begin{tabular}{llllll}
1.2 & 0.0 & 0.4 & $67.08^{\mathrm{i}} \pm 0.82$ & $6.76^{\mathrm{cde}} \pm 0.34$ & $5.2^{\mathrm{a}} \pm 0.82$ \\
1.5 & 0.0 & 0.4 & $72.46^{\mathrm{i}} \pm 0.19$ & $10.24^{\mathrm{de}} \pm 0.41$ & $6.6^{\mathrm{def}} \pm 0.12$ \\
1.8 & 0.0 & 0.4 & $62.38^{\mathrm{j}} \pm 1.61$ & $8.21^{\mathrm{e}} \pm 1.21$ & $5.1^{\mathrm{f}} \pm 0.04$ \\
0.0 & 0.3 & 0.0 & $32.16^{\mathrm{a}} \pm 1.24$ & $2.13^{\mathrm{ab}} \pm 1.63$ & $1.5^{\mathrm{abc} \pm 1.61}$ \\
0.0 & 0.3 & 0.0 & $34.45^{\mathrm{b}} \pm 0.82$ & $3.03^{\mathrm{ab}} \pm 0.71$ & $2.2^{\mathrm{b}-\mathrm{f}} \pm 0.16$ \\
0.0 & 0.3 & 0.0 & $39.34^{\mathrm{d}} \pm 1.63$ & $4.00^{\mathrm{abc}} \pm 1.60$ & $3.1^{\mathrm{abc} \pm 0.82}$ \\
0.0 & 0.3 & 0.0 & $42.04^{\mathrm{d}} \pm 0.27$ & $4.75^{\mathrm{bcd}} \pm 0.41$ & $3.4^{\mathrm{a}-\mathrm{d}} \pm 0.33$ \\
0.0 & 0.3 & 0.0 & $40.28^{\mathrm{e}} \pm 1.17$ & $4.00^{\mathrm{cde}} \pm 1.23$ & $2.5^{\mathrm{ab}} \pm 0.41$ \\
0.0 & 0.3 & 0.0 & $38.17^{\mathrm{e}} \pm 0.82$ & $3.67^{\mathrm{abc}} \pm 0.82$ & $2.2^{\mathrm{a}-\mathrm{d}} \pm 0.16$ \\
\hline \multicolumn{4}{l}{ Means in columns followed by different letter (s) are significant to each other at 5\% level according to DMRT. }
\end{tabular}

Table 4. Effect of different composition of hardening medium on survivability rate of leaf callus derived plantlets of the species, Azima tetracantha.

\begin{tabular}{cccc}
\hline Hardening medium composition (V/V) & $\begin{array}{c}\text { No. of plantlets } \\
\text { under hardening }\end{array}$ & $\begin{array}{c}\text { No. of } \\
\text { plantlets } \\
\text { survived }\end{array}$ & $\begin{array}{c}\text { Survivability } \\
\text { (\%) }\end{array}$ \\
\hline Red soil + sand (1:1) & 50 & 24 & $42^{\mathrm{a} \pm 1.23}$ \\
Garden soil + sand + vermicompost (1:1:1) & 50 & 43 & $75^{\mathrm{e} \pm 0.42}$ \\
Decomposed coir waste + perlite + compost (1:1:1) & 50 & 37 & $70^{\mathrm{d} \pm 0.41}$ \\
Vermicompost + soil (1:1) & 50 & 31 & $68^{\mathrm{c} \pm 1.17}$ \\
Red soil + sand + vermicompost (1:1:1) & 50 & 28 & $57^{\mathrm{b}} \pm 0.82$ \\
\hline
\end{tabular}

Means in column followed by different letter (s) are significant to each other at $5 \%$ level according to DMRT.
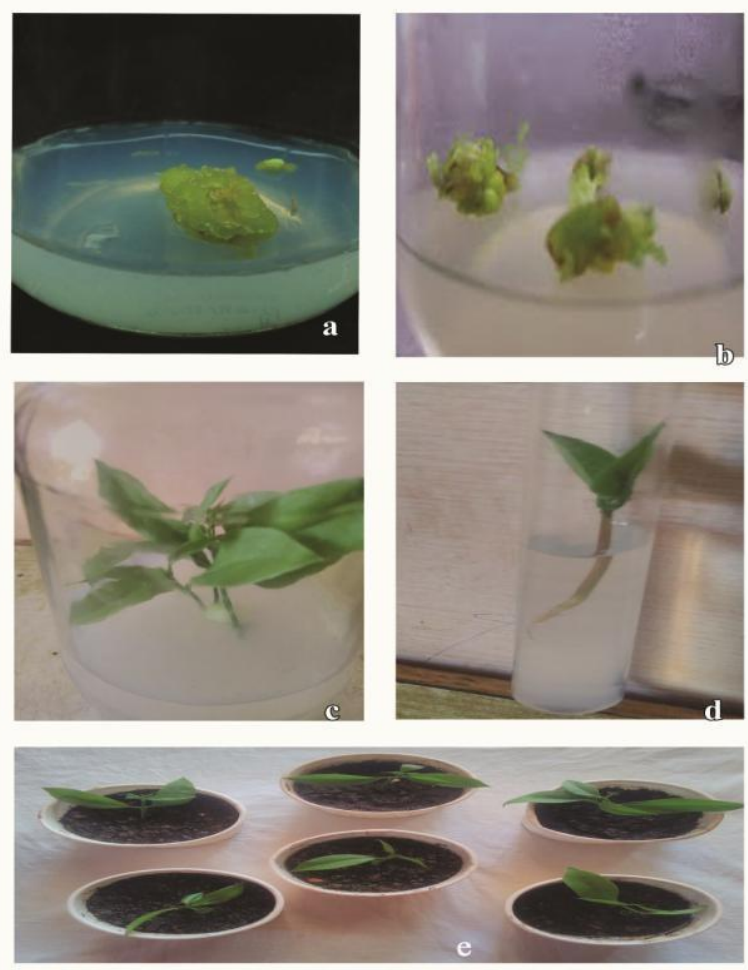

Fig. 1. In vitro regeneration through leaf explant

\section{Azima tetracantha.}

a-b : Effective callusing in MS medium supplemented with BAP and NAA at 1.0 and $0.4 \mathrm{mg} / \mathrm{L}$ respectively. c: Successful shooting by subculturing of leaf derived callus in the MS medium with BAP and NAA at 1.5 and $0.3 \mathrm{mg} / \mathrm{L}$ respectively. $\mathrm{d}$ :High amount of rooting during the subculturing of shoots in the MS medium fortified with IBA and $\mathrm{Kn}$ at 1.5 and $0.4 \mathrm{mg} / \mathrm{L}$ respectively. e: Under hardening in the mist chamber.
Induction of rooting is an important step for in vitro plant propagation. Excised shoots were inoculated on MS medium with IBA and Kn for proper root development. The rooting responses were summarized in Table 3. Maximum rooting (72\%), number of roots (10.24 roots/ shoot) and root length $(6.6 \mathrm{~cm})$ was observed on the MS medium supplemented with IBA and Kn at 1.5 and $0.4 \mathrm{mgl}^{-1}$ respectively (Table 3 ). These findings are in agreement with those reported by Sreekumar et al., 2000; Martin, 2002; Raghuramulu et al., 2002 and Chakradhar and Pullaih, 2014.

After the development of roots, the plantlets were taken out from the culture bottles and washed with sterilized distilled water to remove adhering agar medium, so that the chance of contamination could be stopped. Then these juvenile plantlets were transferred to the hardening medium containing garden soil, sand and vermicompost (1:1:1 ratio by volume) where the leaf callus derived plantlets survivability rate was higher $75 \%$ (Table 4). Admixture of all these three components may offer condusive environment by providing proper nutrients, adequate aeration and required minerals respectively to the plantlets. From the above study, it is concluded that multiple shoot and root cultures of Azima tetracantha were established from leaf explants on MS medium supplemented with combination of hormones. This protocol has potential for large-scale micropropagation and 
application in molecular plant breeding research programs.

\section{REFERENCES}

Chakradhar, T. and T. Pullaih, (2014). In vitro regeneration through adventitious buds in Wattakaka volubilis, a rare medicinal plant. African J. Biotechnol 13(1): 55-60.

Faisal, M. and M. Anis, (2003). Plant cell Tissue Organ Cult 75: 125-129.

Gamborg, O.L. and G.C. Phillips, (1995). Laboratory facilities, operation and management. In: Gamborg OL and Phillips GC (eds.), Fundamental methods of plant cell, tissue and organ culture. Springer, Berlin, NewYork; pp. 320.

Hussain, M. and M. Anis, (2006). Acta Physiol. Plant 28: $325-330$.

Jebakumar, M. and M. Jayabalan, (2000). Plant cell Biotechnol. Mol. Biol 1: 37-40.

Martin, K.P. (2002). Rapid propagation of Holostemma ada-kodien Schult a rare medicinal plant, through axillary bud multiplication and indirect organogenesis. Plant Cell Rep 21: 112117.

Murashige, T. and F. Skoog, (1962). A revised medium for rapid growth and bioassays with tobacco tissue cultures. Physiol. Plant 15: 473497.

Raghuramulu, D., K.S.R. Murthy and T. Pullaiah, (2002). In vitro propagation of Cynanchum callialatum. J. Trop. Med. Plants 3: 233-238.

Raja, H., David and D.I. Arockiasamy, (2008). Plant Cell Tissue Organ Cult 18: 1-6.

Sreekumar, S., S. Seeni and P. Pushpangadan, (2000). Micropropagation of Hemidesmus indicus for cultivation and production of 2-hydroxy 4methoxy benzaldehyde. Plant Cell Tissue Organ Cult 62: 211-218.

Thambiraj, J. and S. Paulsamy, (2012). Rapid in vitro multiplication of the ethnomedicinal shrub, Acacia caesia (L.) Willd. (Mimosaceae) from leaf explants. Asian Pacific J. Trop. Biomed 618-622.

Uniyal, B. (2003). Utilization of medicinal plants by the rural women of Kulu, Himachal Pradesh. Ind. J. Trad. Know 2(4): 366-370. 